\title{
Building Retrofitting System Based on Bamboo-Steel Hybrid Exoskeleton Structures: A Case Study
}

\author{
Vittoria F. Parrella and Luisa Molari *
}

Citation: Parrella, V.F.; Molari, L. Building Retrofitting System Based on Bamboo-Steel Hybrid Exoskeleton Structures: A Case Study.

Sustainability 2021, 13, 5984.

https://doi.org/10.3390/su13115984

Academic Editor: Asterios Bakolas

Received: 19 April 2021

Accepted: 19 May 2021

Published: 26 May 2021

Publisher's Note: MDPI stays neutral with regard to jurisdictional claims in published maps and institutional affiliations.

Copyright: (c) 2021 by the authors. Licensee MDPI, Basel, Switzerland. This article is an open access article distributed under the terms and conditions of the Creative Commons Attribution (CC BY) license (https:/ / creativecommons.org/licenses/by/ $4.0 /)$.
DICAM, Alma Mater Studiorum-Università di Bologna, Viale Risorgimento, 240136 Bologna, Italy; vittoria.parrella@studio.unibo.it

* Correspondence: luisa.molari@unibo.it

\begin{abstract}
The building heritage of many seismic regions worldwide is largely substandard and seismically deficient and would require seismic retrofitting interventions. The use of natural materials with low embedded emissions could lead to a low carbon footprint of the retrofitting intervention. In this perspective, an innovative structural sustainable retrofitting system is proposed consisting of a hybrid steel-bamboo reticular bracing system. Through a preliminary two-dimensional analysis, the capabilities of the system are assessed by varying the size and the number of the culms and inserting engineered bamboo and steel rods. Considering the constraints posed by the openings, a structure that uses steel in the first inter-storey and bamboo in the others is proposed to obtain a significative improvement of mechanical performances. The spatial behaviour of this structure is studied through a three-dimensional numerical model. The seismic analyses show that the exoskeleton structure when conveniently anchored allows to achieve an effective displacement and deformation control on the primary structure, as well as a reduction of its internal forces. The results of the presented work may provide useful preliminary insights. Further research effort is needed to generalize the results to different seismic zones. The proposed seismic retrofitting system could be easily integrated with a thermal coat to also enhance energy saving.
\end{abstract}

Keywords: structural exoskeleton; bamboo; safety; integrated renovation; seismic retrofitting

\section{Introduction}

In many parts of the world, including Europe, design of new buildings for earthquake resistance is a relatively recent development. In many regions, resistance of buildings to lateral forces resulted in the past only from wind considerations. Provisions for seismic design and detailing of members and structures resembling those found in modern seismic codes did not appear before the mid-1970s in US standards, or the mid-1980s in European national codes. Therefore, in the light of current knowledge, the building heritage of many seismic regions worldwide is largely substandard and seismically deficient [1].

According to the fib bulletin 24 [2], as reported in [3], the seismic retrofit intervention in reinforced concrete (RC) buildings can be classified as local, at member level, or global, at structural level.

The most common interventions at member level are:

- $\quad$ Fibre reinforced polymers or textiles embedded in mortar or in cementitious matrix wrapping to infill RC frame or members [4];

- $\quad$ Steel jacketing, steel plate or profiles bonded on the perimeter of the RC member [5]; - $\quad$ RC jacketing to increase of the member's cross section by adding new concrete [6].

The seismic retrofit interventions at the structural level are mainly:

- Steel bracing consists in the installation of diagonal steel braces in some bays connected to the existing RC members, increasing the strength and dissipation capacity of the structure [7,8]; 
- Exterior buttress/exoskeleton consists in the addition of lateral resisting structural systems outside the building, and it reduces the level of forces insisting on the existing building [9,10];

- $\quad$ RC wall addition by infilling strategic bays to control the lateral drift and the damage to structural and non-structural components;

- $\quad$ Base isolation [11,12].

Regarding retrofitting techniques that involve the use of an exoskeleton, there are two innovative techniques recently published. The first one, with dual function of insulation and seismic improvement, develops a seismic coat composed of a thin reinforced concrete slab thrown inside a cast consisting of two layers of insulating material, bound to the existing structure by metal connectors [13-15]. The second technique uses the external lattice steel of diagrid structures, that can efficiently absorb the shear forces produced by horizontal actions [16].

In addition, existing buildings are characterized by a high thermal insulation deficit, mainly due to the legislative delay in adopting appropriate design criteria. The demand for passive thermal performance has grown significantly in recent years as regulations have gradually aligned with global targets with the Kyoto Protocol.

The building integrated retrofit can be an innovative technological solution that allows to increase both the seismic and energy performance [3,17].

This technique should consider not only the effectiveness in terms of seismic and energy performance, but also aspects related to the use of natural materials with low embedded emissions to improve other aspects like the life cycle assessments of the structures and lower the carbon footprint of the retrofitting intervention.

Within this context, a global structural retrofit system, which could be easily integrated in a more complex structural-energetic one, is proposed to guarantee seismic improvement through the use of an unconventional sustainable material like bamboo.

Bamboo has a high carbon sequestration ability, which could lead to even a possibly negative carbon footprint of bamboo products as reported by the INBAR report $[18,19]$. Replacing high $\mathrm{CO}_{2}$ emitting materials like metals, plastic or concrete with bamboo could lead to a high $\mathrm{CO}_{2}$ reduction.

In the literature, there are some studies, although not many, that explore the possibility of using bamboo for seismic improvement of existing buildings [20,21], as it represents an economical, sustainable and well-performing mechanical material [22-24].

Here, an external global seismic retrofitting system constituted of a counter-bracing system, a sort of exoskeleton, consisting of bamboo rods, able to relieve the existing structure of a part of the floor shear forces and reduce the movements of the planes is proposed.

The paper is organized as follows. After the introduction, in Section 2, the purpose and retrofitting strategies are defined, presenting the bamboo exoskeleton as a retrofitting system. Section 3 shows the effectiveness of the system in the case study of a framed structure in reinforced concrete. Conclusions are finally drawn in Section 4.

\section{Bamboo Exoskeleton: Retrofitting System}

Seismic retrofitting of buildings is effective in mitigating the seismic risk represented by a substandard building heritage. The purpose is to modify seismic demands, named $E_{d}$, and/or capacities, named $R_{d}$, so that all relevant elements of the building meet the general verification inequality, $\mathrm{E}_{\mathrm{d}} \leq \mathrm{R}_{\mathrm{d}}$, at all performance levels [1]. The design of the exoskeleton provides for the reduction of seismic stresses on the members and on the whole structure, through the insertion of an external reinforcement structure suitably connected to the existing building.

To understand the role played by the exoskeleton, it is possible to roughly model the original structure as a viscoelastic oscillator (1), to which a second viscoelastic oscillator (the exoskeleton) (2) is connected $[9,10]$. The two oscillators are joined by a Hooke link consisting in a spring of stiffness K (Figure 1). 


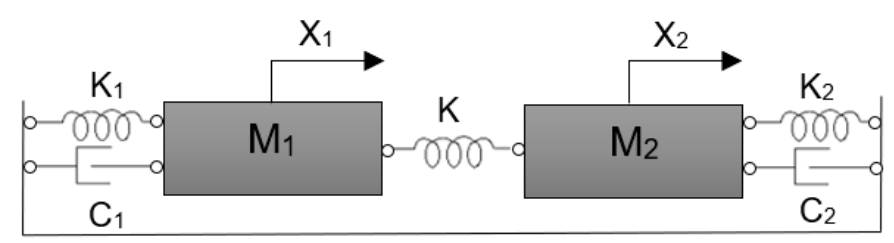

Figure 1. Structural model that considers two viscoelastic oscillators, original structure-exoskeleton, with Hooke link consisting in a spring of stiffness $\mathrm{K}$.

$X_{i}, M_{i}, K_{i}$ and $C_{i}$ indicate coordinate, mass, stiffness and damping coefficients of the i-th oscillator, respectively. Denoting relative displacements with $U_{i}$, the dynamic equilibrium exited from ground motion $X_{g}(t)$ is:

$$
\begin{aligned}
& M_{1} \ddot{U}_{1}+C_{1} \dot{U}_{1}+K_{1} U_{1}=-M_{1} \ddot{X}_{g}+K\left(U_{2}-U_{1}\right), \\
& M_{2} \ddot{U}_{2}+C_{2} \dot{U}_{2}+K_{2} U_{2}=-M_{2} \ddot{X}_{g}-K\left(U_{2}-U_{1}\right)
\end{aligned}
$$

with $U_{1}=X_{1}-X_{g}$ and $U_{2}=X_{2}-X_{g}$.

The elastic coupling between the two oscillators can be supposed as rigid, so $\mathrm{K} \rightarrow \infty$, therefore $U_{2} \rightarrow U_{1}$, and it is possible to reduce the previous equations (1) to a SingleDegree-Of-Freedom system:

$$
\left(M_{1}+M_{2}\right) \ddot{U}_{1}+\left(C_{1}+C_{2}\right) \dot{U}_{1}+\left(K_{1}+K_{2}\right) U_{1}=-\left(M_{1}+M_{2}\right) \ddot{X}_{g}
$$

The exoskeleton increases the mass of the original structure and its stiffness. The increase in mass leads to modify inertia forces. Using a bamboo retrofitting system, the mass increment is low in respect to the use of other materials, due to the light mass of bamboo culm. The increase in stiffness allows to reduce interplane displacements, reducing possible damage. Research interest in bamboo derives from the fact that it is both a structural and sustainable material, very renewable because it grows rapidly and reaches its maximum mechanical strength in 3-5 years and it allows a larger amounts of $\mathrm{CO}_{2}$ absorption in respect to many other tree species $[19,22]$. In the field of civil engineering, it can be used both in its engineered and natural form. Although the variability of the final values is very high, the average compression resistance can reach $100 \mathrm{MPa}$, the average tensile strength $350 \mathrm{MPa}$, and the elasticity module in tension and compression $25.000 \mathrm{MPa}$ [22]. In the following, we consider Italian bamboo as detailed in the next Section.

\section{Case Study}

A reinforced concrete framed building located in Bologna, Italy, is considered as the building to retrofit. The building was conceived with characteristics similar to those built in Italy in the 1970s [25] when the horizontal actions resulted only from considerations about wind loads.

It consists of 4 -storeys, 4 bays by 2 bays. The building plan has a double symmetry, and the span lengths are $5.9 \mathrm{~m}, 6.5 \mathrm{~m}, 6.5 \mathrm{~m}$ and $5.9 \mathrm{~m}$, respectively, in longitudinal direction and $6 \mathrm{~m}$ in transverse direction (as shown in Figure 2). Inter-storey heights are $3.2 \mathrm{~m}$, except the first one, which is $3.5 \mathrm{~m}$. The roof is flat. Column cross-sections are squared with dimensions $45 \mathrm{~cm} \times 45 \mathrm{~cm}$ in the first inter-storey and a decrease of $5 \mathrm{~cm}$ per side going up, reaching on the top a square of $30 \mathrm{~cm} \times 30 \mathrm{~cm}$. The edge beams and secondary inner beams (represented in green in Figure 2) have a rectangular cross-section of size $30 \mathrm{~cm} \times$ $65 \mathrm{~cm}$, while the main beams have a T-cross section with height $65 \mathrm{~cm}$, width $60 \mathrm{~cm}$ and thickness $30 \mathrm{~cm}$. The building has $25 \mathrm{~cm}$ floor slab in hollow clay brick, reinforced with an upper concrete slab $5 \mathrm{~cm}$ thick. 


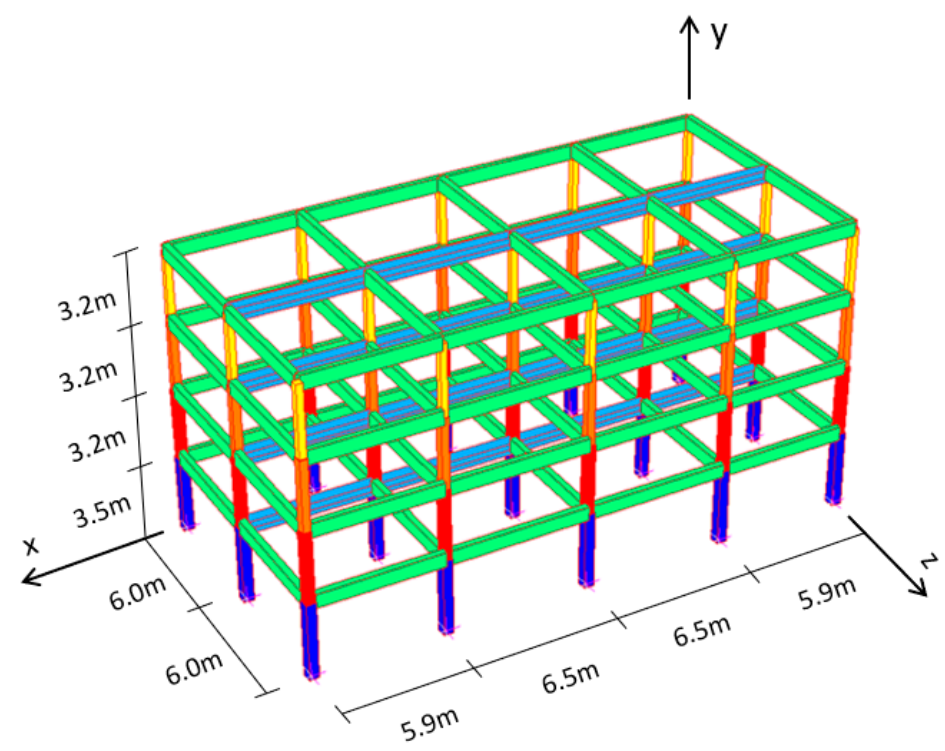

Figure 2. Original structure: three-dimensional geometry.

\subsection{Proposed Bamboo Retrofitting System Applied to Reinforced Concrete Frame}

The aim of the paper is to use an exoskeleton as a retrofitting system characterized by a bamboo lattice system embracing the existing structure. In this way, there is the advantages of a grid structure coupled with the advantage of an external coat integrable with an energetic system.

The choice is to use a bamboo grown in Italy. In particular, Iridescens (IRI) species is chosen, because it is the one with the best mechanical performance among those cultivated in temperate climate [23]. Table 1 shows the design values obtained from the experimental data reported in [23], compliant with ISO standards [26-28] and Colombian standards [29].

Table 1. Design values species Iridescens in relation to ISO [26-28] and Colombian standards [29].

\begin{tabular}{ccc}
\hline Species & \multicolumn{2}{c}{ Phyllostachys Iridescens } \\
\hline Normative & ISO [26-28] & Colombian [29] \\
Traction (MPa) & 60.0 & 36.2 \\
Compression (MPa) & 27.3 & 28.1 \\
Elastic modulus (GPa) & 19.33 & 19.33 \\
\hline
\end{tabular}

\subsection{Method of Analysis and Characterization Seismic Action}

The modal analysis with response spectrum is used as a method of analysis, according to the Italian Building Code [30,31]. The analysis consists of two steps: the determination of vibrational modes with calculation of the effects of seismic action for each mode and the combination of these through modal overlap techniques. In the present case, reference is made to the SRSS rule [30,31]. Seismic action is modelled across the design spectrum, which is defined site by site as the return period of the earthquake changes according to Italian Building Code [30,31]. Seismic demand can be reduced through the behaviour structure factor $q$. The Damage Limitation State (DLS) is considered as $q=1$, the structure remains in the elastic field, while for the Life-safety Limit State (LLS), $q=2.5$ is assumed, referring to a study conducted by Vona on the Italian building heritage [25,32]. The pseudo-acceleration spectral forms in Figure 3 are obtained. 


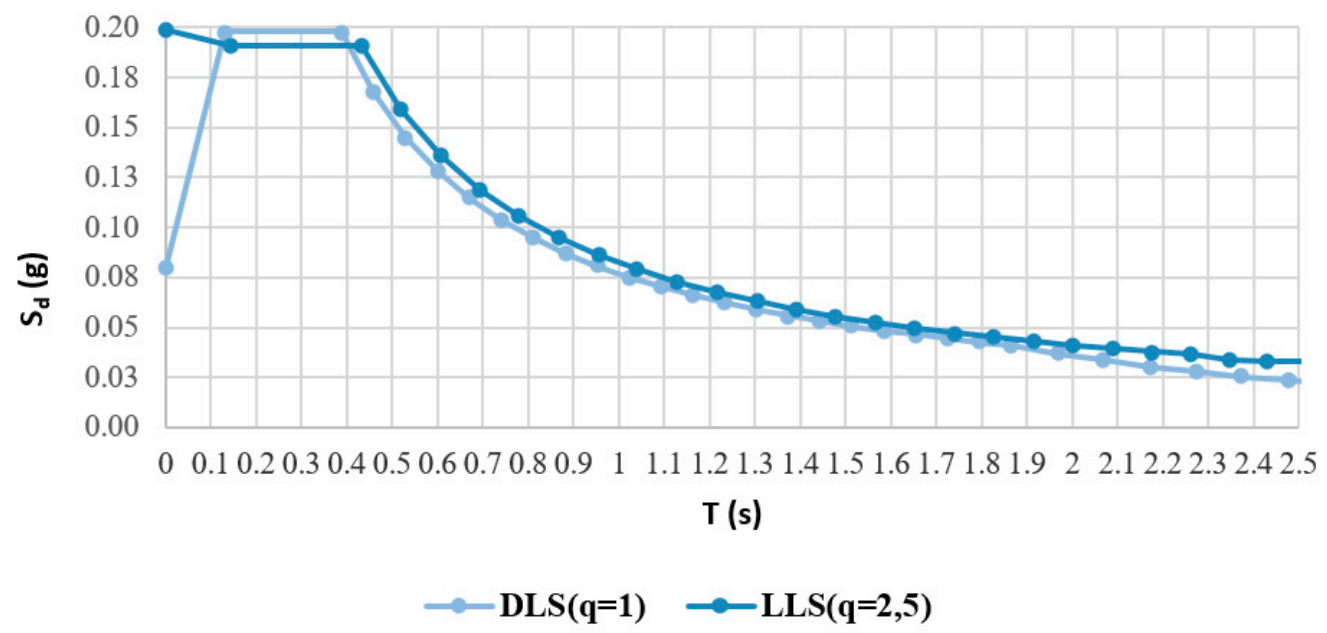

Figure 3. Design response spectrum function of pseudo-acceleration, $S_{d}$, defined for DLS (Damage Limitation State) and LLS (Life-safety Limit State) with 5\% viscous damping.

\subsection{Two-Dimensional Preliminary Analysis of Retrofitting System Capabilities}

A two-dimensional preliminary analysis evaluates the capabilities of the retrofitting system anchored on the external frame of the existing structure in longitudinal direction.

In the numerical analysis floor slabs are considered rigid in-plane and the structure is considered fixed at the base, neglecting interactions with the ground. We consider the translational masses, which take into account the translational inertia of the structure.

Translational masses are defined from the weights associated for each level. Considering the infinitely rigid plane and having the columns of equal stiffness, the part share of the plane mass, associated with the external frame in longitudinal direction, is calculated by dividing the mass associated with each plane by three (see Table 2).

Table 2. Translational masses, for exterior frame in longitudinal direction, defined from the weights associated for each level.

\begin{tabular}{ccc}
\hline & Weights (kN) & Translational Mass (kg) \\
\hline Level 1 & 3427 & 116,461 \\
Level 2 & 3352 & 113,889 \\
Level 3 & 3310 & 112,462 \\
Level 4 & 2263 & 76,898 \\
\hline
\end{tabular}

In order to evaluate the effectiveness of the application of a bracing lattice to the original structure, modal parameters and DLS shear forces are compared. An initial comparison does not take into account the shear forces at the LLS, since the response spectra to DLS and LLS have almost the same values for the periods of interest (see Figure 3 and Table 3). The modal parameters of the original frame in the absence of the retrofitting system are reported in Table 3, and the floor shear forces with response spectrum are collected in Table 4.

Table 3. Modal parameters of the original structure: exterior frame x- direction.

\begin{tabular}{cccc}
\hline & Pulsation $(\mathbf{r a d} / \mathbf{s})$ & Period $(\mathbf{s})$ & Frequency $(\mathrm{Hz})$ \\
\hline Mode 1 & 9.55 & 0.66 & 1.52 \\
Mode 2 & 23.77 & 0.26 & 3.78 \\
Mode 3 & 36.29 & 0.17 & 5.78 \\
Mode 4 & 52.86 & 0.12 & 8.42 \\
\hline
\end{tabular}


Table 4. Floor shear forces exterior frame (DLS).

\begin{tabular}{lc}
\hline & Floor Shear Forces (kN) \\
\hline Level 1 & 401.8 \\
Level 2 & 351.87 \\
Level 3 & 267.64 \\
Level 4 & 148.12 \\
\hline
\end{tabular}

The lattice bracing system shown in Figure 4a is then applied to the external frame in the plane of the frame (Figure $4 \mathrm{~b}$ ), neglecting in a first approximation the presence of openings on the façade.

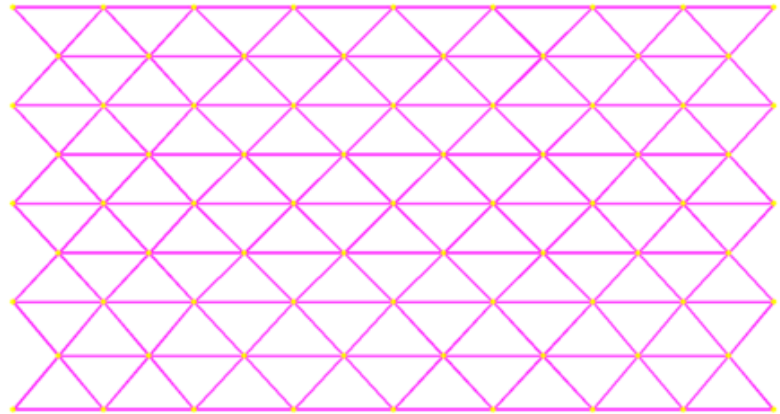

(a)

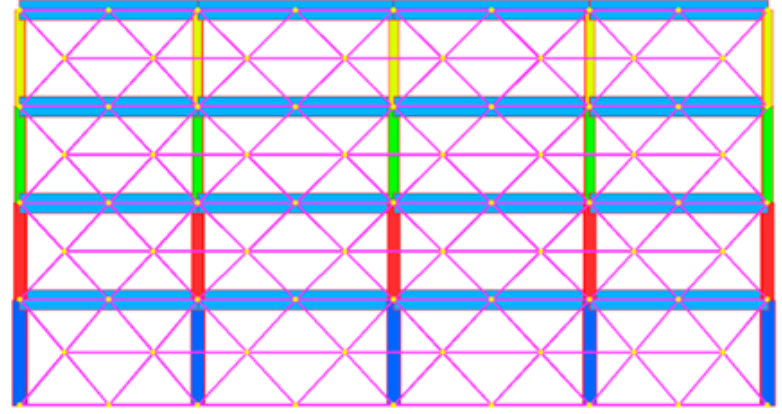

(b)

Figure 4. Retrofitting system (a) anchored to exterior frame (b).

A number of different configurations of the lattice bracing system is considered by varying the size and the numbers of the culms per rod and evaluating later the effectiveness of using engineered bamboo.

The following configurations are analysed with each rod consisting of:

1 IRI culm (75 mm external diameter and $8 \mathrm{~mm}$ thickness);

2 IRI culms (75 $\mathrm{mm}$ external diameter and $8 \mathrm{~mm}$ thickness);

1 IRI culm (90 mm external diameter and $9 \mathrm{~mm}$ thickness);

2 IRI culms (90 $\mathrm{mm}$ external diameter and $9 \mathrm{~mm}$ thickness);

3 IRI culms (90 $\mathrm{mm}$ external diameter and $9 \mathrm{~mm}$ thickness).

Modal analysis and response spectrum analysis are repeated for each configuration. The results are compared in terms of modal parameters and floor shear forces in relation to the structure without retrofit. In particular, Table 5 reports the reduction of the periods as a percentage. Note that as the cross-sectional area of the culms and the number of culms per rod increase, the period is reduced as the structure becomes stiffer. This highlights that the insertion of the lattice increases the stiffness of the frame, thus reducing plane movements.

Table 5. Reduction of period $\mathrm{T}$, as a percentage, compared to frame without retrofit, for lattices with bamboo culms.

\begin{tabular}{lccccc}
\hline \multicolumn{7}{c}{ Iridescens (n.culm/Diameter $\boldsymbol{\phi}[\mathbf{m m}])$} \\
\hline 1/\$75 & $\mathbf{2 / \boldsymbol { 9 7 5 }}$ & $\mathbf{1 / \boldsymbol { 9 9 0 }}$ & $\mathbf{2 / \boldsymbol { 9 0 }}$ & $\mathbf{3 / \boldsymbol { 9 0 }}$ \\
\hline Mode 1 & 24 & 36 & 29 & 42 & 49 \\
Mode 2 & 28 & 40 & 33 & 45 & 52 \\
Mode 3 4 & 23 & 35 & 28 & 41 & 48 \\
\hline
\end{tabular}

Additionally, the floor shear forces are reduced increasing the number and the cross sections of the rods as shown in Table 6. In particular, the results show that the bracing 
system is able to relieve the column on the upper floors where the original structure has columns with a smaller cross, while in the first inter-storey, the shear forces reduction is very small.

Table 6. Reduction floor shear forces to the DLS, as a percentage, for the different configurations: lattices with bamboo culms and engineered bamboo, in relation to the retrofit-free structure.

\begin{tabular}{|c|c|c|c|c|c|c|c|c|c|}
\hline \multicolumn{10}{|c|}{ Iridescens (n.culm/Diameter $\phi[\mathrm{mm}]$ )/Engineered Bamboo (Eng. Bam) } \\
\hline & $1 / \phi 75$ & $2 / \phi 75$ & $1 / \phi 90$ & $2 / \phi 90$ & $3 / \phi 90$ & $\begin{array}{l}\text { Eng. Bam } 1 \\
\text { Floor } \\
\text { 1/ф90 Other } \\
\text { Floors }\end{array}$ & $\begin{array}{l}\text { Eng. Bam } 1 \\
\text { Floor } \\
2 / \phi 90 \text { Other } \\
\text { Floors }\end{array}$ & $\begin{array}{c}\text { Eng. Bam } 1 \\
\text { Floor } \\
\text { 3/ф90 Other } \\
\text { Floors }\end{array}$ & Eng. Bam \\
\hline Level 1 & 2 & 7 & 4 & 13 & 29 & 76 & 67 & 64 & 61 \\
\hline Level 2 & 22 & 35 & 28 & 43 & 58 & 18 & 42 & 57 & 68 \\
\hline Level 3 & 36 & 51 & 43 & 58 & 70 & 34 & 35 & 70 & 78 \\
\hline Level 4 & 57 & 72 & 64 & 77 & 84 & 57 & 76 & 84 & 89 \\
\hline
\end{tabular}

Since the reduction at the first level is not significative, in the first inter-storey the bamboo culms are substituted by engineered bamboo rods with a cross section of $15 \mathrm{~cm} \times$ $15 \mathrm{~cm}$, leaving bamboo culms in the other floors; reference is made also to a lattice structure completely made of engineered bamboo. Engineered bamboo refers to scriber bamboo, whose mechanical performance is defined in [33]. The percentage reduction of floor shear forces in these configurations are reported in the last columns of Table 6.

As it can be seen in Table 6, for the two configurations that involve the engineered bamboo on floor 1 and, respectively, a culm and two culms on the upper ones, there is an excessive stiffening of floor 1 compared to the other floors that can hinder the formation of a global collapse mechanism. The combination of engineered bamboo at the first inter-storey and three bamboo culms at the higher level has almost the same performance of a fully engineered bamboo grid. Taking into account the greater sustainability of bamboo in its natural form, the optimal configuration is defined as the system that presents engineered bamboo on the first floor and three bamboo culms per rod on the upper floors.

Starting from this configuration, the possible presence of openings is taken into account. In particular the openings shown in Figure $5 \mathrm{~b}$ are considered.

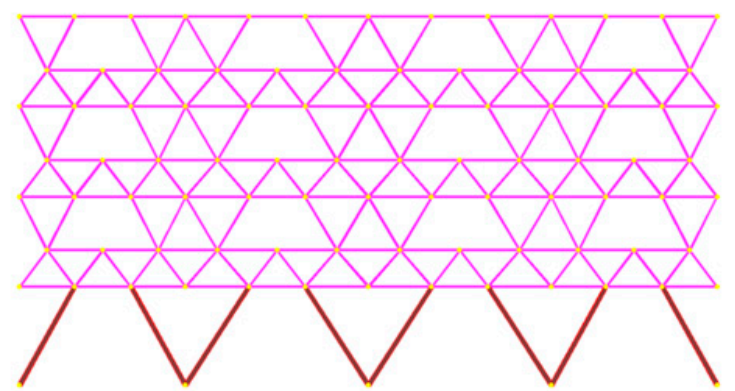

(a)

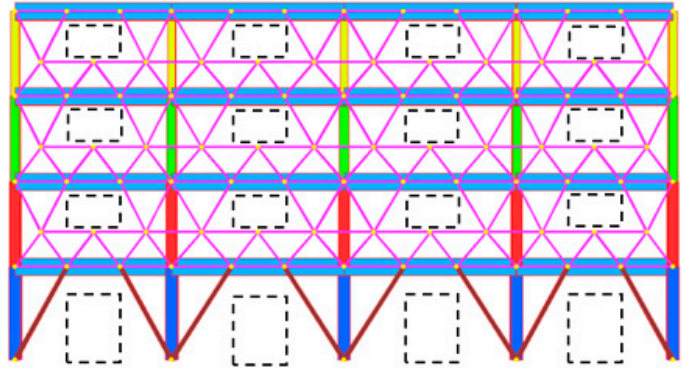

(b)

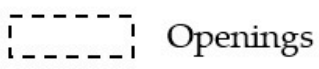

Figure 5. Retrofitting system in the presence of openings (a) anchored to exterior frame (b).

The grid is modified accordingly, and in this new configuration, the reduction of the floor shear forces on inter-storey 1 is much lower than in previous cases (Table 7). 
Table 7. Reduction of floor shear forces to the DLS, as a percentage, for lattices in the presence of openings, in relation to the retrofit-free structure.

\begin{tabular}{ccc}
\hline & $\begin{array}{c}\text { Eng. Bam 1rst Floor } \\
+\mathbf{3} \mathbf{\phi 9 0} \mathbf{~ m m ~ O t h e r ~ F l o o r s ~}\end{array}$ & $\begin{array}{c}\text { Steel 1rst Floor } \\
\mathbf{+ 3 / \mathbf { 9 0 }} \mathbf{~ m m} \text { Other Floors }\end{array}$ \\
\hline Level 1 & 20 & 48 \\
Level 2 & 47 & 47 \\
Level 3 & 63 & 62 \\
Level 4 & 79 & 78 \\
\hline
\end{tabular}

As reported in Table 7, it is necessary to replace the engineered bamboo on inter-storey 1 with steel profiles (hollow normalized profile with circular section, external diameter $101.6 \mathrm{~mm}$ and thickness $10 \mathrm{~mm}$ ) to obtain a significative reduction of floor shear forces, in fact the reduction goes from $20 \%$ to $48 \%$ employing steel instead of engineered bamboo.

\subsection{Spatial Structural Behavior Analysis: Hybrid Steel-Bamboo Lattice System}

In order to analyse the spatial behaviour of the structure, the retrofitting system with hybrid steel-bamboo lattice system model is considered in a three-dimensional context (Figure 6).

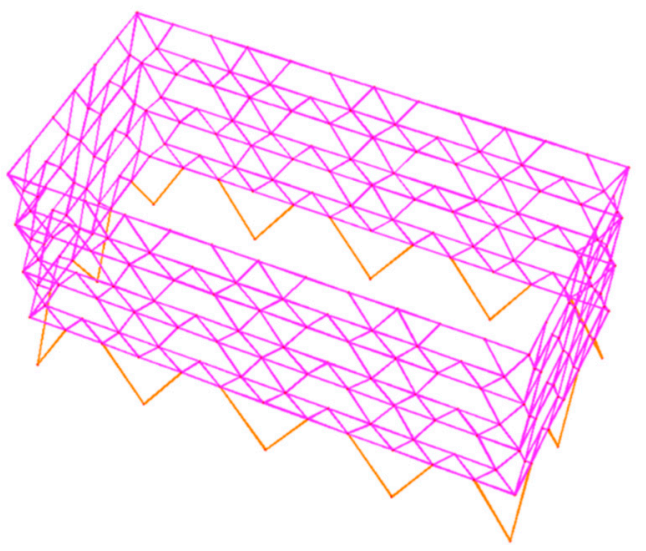

Figure 6. Hybrid steel-bamboo lattice system.

In a three-dimensional model, in addition to the translational masses, the rotational masses (connected to rotational inertia) are considered. Translational masses are defined in the longitudinal and transversal directions and rotational masses around vertical axis. The rotational inertia of the masses, with respect to the centre of gravity, is defined as follows:

$$
M_{i G}=\frac{M_{i}\left(a^{2}+b^{2}\right)}{12}
$$

where $M_{i}$ represents the mass of i-floor, a and $\mathrm{b}$ represent the size of the floor in the plane.

The weights, the translational masses and the rotational masses of each inter-storey are collected in Table 8.

Table 8. Translational and rotational masses defined from the weights associated for each level.

\begin{tabular}{cccc}
\hline & Weights (kN) & Translational Mass $\mathbf{( k g )}$ & Rotational Mass $\mathbf{( k g m}^{\mathbf{2}} \mathbf{)}$ \\
\hline Level 1 & 3427.4 & 349,383 & $22,099,623$ \\
Level 2 & 3351.8 & 341,667 & $21,611,598$ \\
Level 3 & 3309.8 & 337,386 & $21,340,789$ \\
Level 4 & 2263.1 & 230,694 & $14,592,140$ \\
\hline
\end{tabular}


The primitive structure is analysed with the elastic modulus E corresponding to a characteristic compression resistance of $30 \mathrm{MPa}$ and with a halved elastic modulus to take into account the mechanical performance of existing damaged buildings. The results differ by a few percentage points, and for brevity, only the results for the structure with the reduced $\mathrm{E}$ are reported. The modal parameters related to the structure without retrofit and with retrofit are compared, confirming a significative reduction in the period of vibration (Table 9).

Table 9. Modal parameters related to the structure with retrofit and without retrofit for the first five mode shapes.

\begin{tabular}{ccccccc}
\hline & \multicolumn{2}{c}{ Pulsation (rad/s) } & \multicolumn{2}{c}{ Period (s) } & \multicolumn{2}{c}{ Frequency (Hz) } \\
\hline & Retrofit & $\begin{array}{c}\text { No } \\
\text { Retrofit }\end{array}$ & Retrofit & $\begin{array}{c}\text { No } \\
\text { Retrofit }\end{array}$ & Retrofit & $\begin{array}{c}\text { No } \\
\text { Retrofit }\end{array}$ \\
\hline Mode 1 & 11.03 & 6.55 & 0.57 & 0.96 & 1.76 & 1.04 \\
Mode 2 & 14.71 & 6.87 & 0.43 & 0.91 & 2.34 & 1.09 \\
Mode 3 & 18.93 & 8.47 & 0.33 & 0.74 & 3.01 & 1.35 \\
Mode 4 & 29.16 & 16.64 & 0.21 & 0.38 & 4.64 & 2.65 \\
\hline
\end{tabular}

The shear forces corresponding to DLS and LLS in longitudinal direction (that are greater than the transversal direction) are reported in Figure 7. In dark blue are indicated the stresses related to the RC frame, given by the sum of the shear forces on each column of the same plane, in the considered direction; in light blue the plane shear forces on the structure without retrofit are indicated. The efficiency of the proposed system is confirmed, and significant reductions in shear forces are obtained in both DLS and LLS cases (Figure 7 and Table 10).
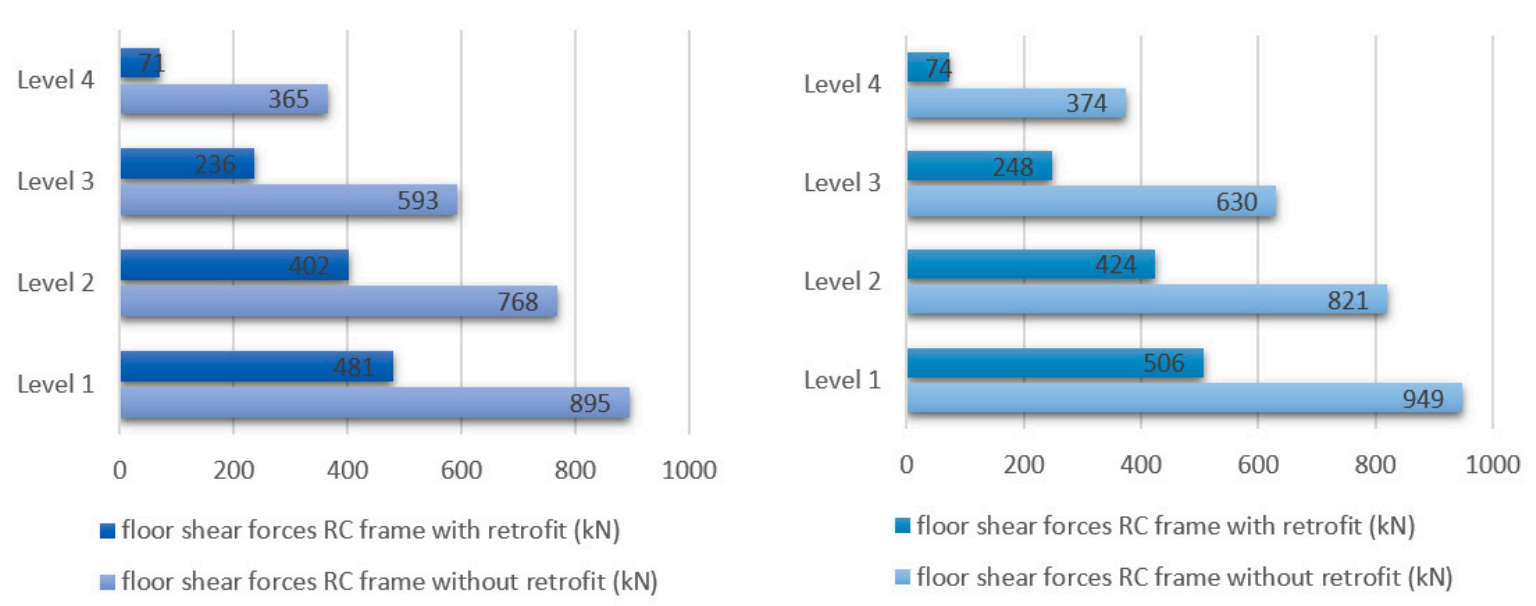

Figure 7. Floor shear forces to the DLS (on the left) and LLS (on the right) in kN (x-direction) in relation to the retrofit-free structure.

Table 10. Percentage reduction of floor shear forces for hybrid steel-bamboo lattice system, in relation to the retrofit-free structure DLS and LLS.

\begin{tabular}{ccc}
\hline & DLS & LLS \\
\hline Level 1 & 46 & 47 \\
Level 2 & 48 & 48 \\
Level 3 & 60 & 61 \\
Level 4 & 81 & 80 \\
\hline
\end{tabular}


The reduction of the period implies an increase in the spectral acceleration but, as can be seen in Figure 3, the increase related to this reduction is low compared to the whole forces insisting on the structure.

Furthermore, the retrofitting system absorbs a significant part of the seismic forces, allowing a significant reduction of the stresses on the original structure, as shown by the difference between the shear forces in the structure with and without retrofitting (Figure 7).

The floor displacements and the inter-floor displacements for DLS state with and without retrofit are reported in Figure 8 and Table 11. A significant reduction is obtained in the case of a structure with the retrofit system here designed.

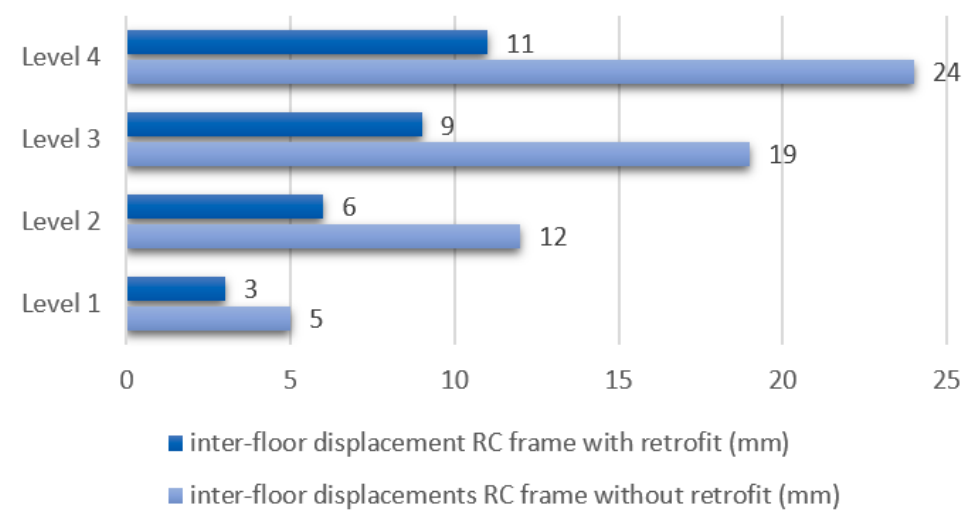

Figure 8. Floor displacements to the DLS in mm (x-direction).

Table 11. Floor drifts (inter-floors displacements) in $\mathrm{mm}$.

\begin{tabular}{ccc}
\hline & Retrofit-Free Structure $\mathbf{( m m )}$ & Retrofit Structure $\mathbf{( m m})$ \\
\hline Level 1 & 5 & 3 \\
Level 2 & 7 & 3 \\
Level 3 & 7 & 3 \\
Level 4 & 5 & 2 \\
\hline
\end{tabular}

The rods of the bracing system are verified at compression or tension and at instabilities in compliance with ISO standards.

\subsection{Hypothesis of Anchoring Original Structure-Retrofitting System}

A possible anchorage of the lattice structure to the original frame is presented in Figure 9. The connection is made with metal plates at the nodes of the primary structure. The plates are connected to the structure through bolts. The rods conferring in the nodes are made in solidarity with the plates by bolting on vertical metal plates, which in turn are welded to the plate connected to the building. The connection with the culms, may have different choices. A possible reference could be the connections used in the GermanChinese house on the occasion of Expo 2010 in Shanghai [34]. Therefore, metal connectors are provided and inserted inside the culms filled with mortar. 


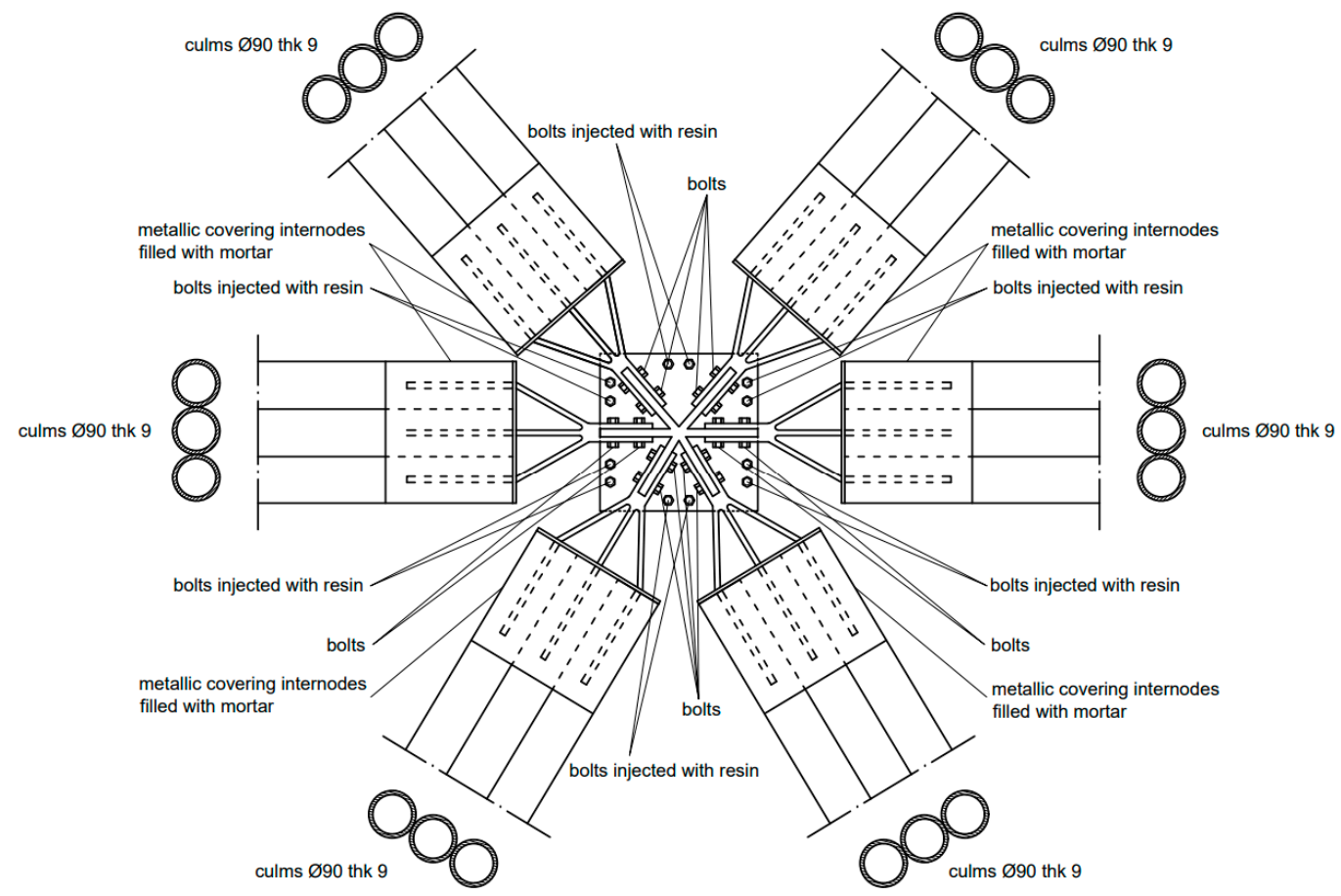

$1 \mathrm{dm}$

Figure 9. Details of the anchorage.

\section{Conclusions}

The study shows the feasibility of the use of bamboo for structural retrofitting of concrete buildings. In particular, an innovative retrofitting system consisting of hybrid steel-bamboo bracing lattices is proposed. The study of this system demonstrates a good effectiveness in terms of reducing both plane displacements and plane drifts and shear forces on the original structure, thanks to the ability of the lattices to take a significant portion of stresses. The reduction reached in terms of shear force at the base, was $46 \%$ in longitudinal direction for DLS and $47 \%$ for LLS. The percentage is similar to that of innovative retrofitting techniques like that of steel lattice braces reported in [9], with the advantages of using sustainable material.

The use of bamboo, like natural materials in general, can raise durability issues which are not fully exploited so far [35]. The proposed bamboo exoskeleton, however, could allow maintenance and substitution of single bar or grid members.

This research represents a first step and opens the perspective of the use of natural sustainable materials like bamboo in structural retrofitting systems.

Similarly, to the concrete seismic coats that have the dual function of energy insulation and seismic improvement, the system here proposed can be inserted in a package with a thermal insulation function in order to also reduce the transmittance values of the envelope and be part of a context of integrated sustainable, structural and energy improvement.

The results of the presented work may provide useful preliminary insights. The study has been conducted for a site like Bologna where the PGA expected is relatively small $(0.2 \mathrm{~g})$, assuming that the retrofitting structure has a ductility compatible with the behaviour factor $q=2.5$ [Masi, Vona]. To quantify the effective excursion capacity in the plastic field of the designed system and of the whole structure, it is necessary to employ a non-linear analysis that can be made with a pushover analysis able to describe the origin and evolution of the plastic mechanisms within the structural system.

Author Contributions: Conceptualization, L.M.; methodology, L.M., V.F.P.; software, V.F.P.; validation, V.F.P.; formal analysis, V.F.P.; data curation, V.F.P.; writing-original draft preparation, L.M., V.F.P.; writing - review and editing, L.M.; supervision, L.M. All authors have read and agreed to the published version of the manuscript. 
Funding: This research received no external funding.

Institutional Review Board Statement: Not applicable.

Informed Consent Statement: Not applicable.

Data Availability Statement: Not applicable.

Conflicts of Interest: The authors declare no conflict of interest.

$\begin{array}{ll}\text { Abbreviations } \\ \text { RC } & \text { Reinforced Concrete } \\ \text { IRI } & \text { Phyllostachys Iridescens } \\ \text { DLS } & \text { Damage Limitation State } \\ \text { LLS } & \text { Life-safety Limit State } \\ \text { Eng. Bam } & \text { Engineered Bamboo }\end{array}$

\section{References}

1. Fardis, M.N. Seismic Design, Assessment and Retrofitting of Concrete Buildings Based on EN-Eurocode 8; Springer: Dordrecht, The Netherlands, 2009; ISBN 978-1-4020-9841-3.

2. Fib. Seismic Assessment and Retrofit of Reinforced Concrete Buildings; Bulletin No. 24; Fib: Lausanne, Switzerland, 2003.

3. Menna, C.; Del Vecchio, C.; Di Ludovico, M.; Mauro, G.M.; Ascione, F.; Prota, A. Conceptual design of integrated seismic and energy retrofit interventions. J. Build. Eng. 2021, 38, 102190. [CrossRef]

4. Pohoryles, D.A.; Bournas, D.A. Seismic retrofit of infilled RC frames with textile reinforced mortars: State-of-the-art review and analytical modelling. Compos. Part B Eng. 2020, 183, 107702. [CrossRef]

5. Islam, N. Strengthening of Reinforced Concrete Columns by Steel Jacketing: A State of Review. IEEE Trans. Eng. Manag. 2015, 5, 6-14.

6. Campione, G.; Fossetti, M.; Giacchino, C.; Minafo, G. RC columns externally strengthened with RC jackets. Mater. Struct. 2014, 47, 1715-1728. [CrossRef]

7. Bush, T.D.; Jones, E.A.; Jirsa, J.O. Behavior of RC frame strengthened using structural-steel bracing. ASCE J. Struct. Eng. 1991, 117, 1115-1126. [CrossRef]

8. Maheri, M.R.; Sahebi, A. Use of steel bracing in reinforced concrete frames. Eng. Struct. 1997, 19, 1018-1024. [CrossRef]

9. Martelli, L.; Restuccia, L.; Ferro, G. The exoskeleton technology as a solution to seismic adjustment of existing buildings. Procedia Struct. Integr. 2020, 26, 175-186. [CrossRef]

10. Reggio, A.; Restuccia, L.; Martelli, L.; Ferro, G.A. Seismic performance of exoskeleton structures. Eng. Struct. 2019, $198,109495$. [CrossRef]

11. Matsagar, V.; Jangid, R.S. Base Isolation for Seismic Retrofitting of Structures. Pract. Period. Struct. Des. Constr. 2008, 13, 175-185. [CrossRef]

12. Mazza, F.; Mazzara, M.; Vulcano, A. Base-isolation systems for the seismic retrofitting of r.c. framed buildings with soft-storey subjected to near-fault earthquakes. Soil Dyn. Earthq. Eng. 2018, 109, 209-221. [CrossRef]

13. Scotta, R.; De Stefani, L.; Pertile, V. Studio Preliminare per la Valutazione Teorica e Analitica della Fattibilità ed Efficacia dell'Adeguamento Sismico di Edifici Esistenti Mediante il Cappotto Armato Ecosism; Report Contract between ECOSIM Srl and ICEA Department; University of Padua: Padua, Italy, 2016.

14. Scotta, R.; De Stefani, L.; Pertile, V. Relazione Interpretativa del Comportamento del Sistema Cappotto Sismico Ecosism sulla Base dei Risultati Sperimentali Ottenuti dalla Campagna di Prove Effettuata; Report Contract between ECOSIM Srl and ICEA Department; University of Padua: Padua, Italy, 2017.

15. Scotta, R.; Stella, A.; De Stefani, L.; Pertile, V. Miglioramento Sismico ed Energetico degli Edifici Esistenti Mediante “Cappotto Sismico": Prove Sperimentali ed Interpretazione dei Risultati. Ingegno. 2019. Available online: https://webapi.ingenio-web.it (accessed on 24 May 2021).

16. Toreno, M.; Arpino, R.; Mele, E.; Brandonisio, G.; De Luca, A. An Overview on Diagrid Structures for Tall Buildings. J. Struct. Eng. World Congr. 2012, 2, 22-28.

17. Mistretta, F.; Stochino, F.; Sassu, M. Structural and thermal retrofitting of masonry walls: An integrated cost-analysis approach for the Italian context. Build. Environ. 2019, 155, 127-136. [CrossRef]

18. van der Lugt, P.; ThangLong, T. Carbon Sequestration and Carbon Emissions Reduction Through Bamboo Forests and Products, INBAR Report. Available online: https://www.inbar.int/resources/inbar_publications/carbon-sequestration-and-carbonemissions-reduction-through-bamboo-forests-and-products/ (accessed on 24 May 2021).

19. De Falder, K.; Rovers, R. One laminated bamboo-frame house per hectare per year. Constr. Build. Mater. 2009, $23,210-218$.

20. Meguro, K.; Soti, R.; Navaratnaraj, S.; Numada, M. Dynamic Testing of Masonary Houses Retrofitted by Bamboo Band Meshes. J. Jpn. Soc. Civ. Eng. 2012, 68, 760-765. [CrossRef] 
21. Rafi, M.M.; Lodi, S. Comparison of dynamic behaviours of retrofitted and unretrofitted cob material walls. Bull. Earthq. Eng. 2017, 15, 3855-3869. [CrossRef]

22. Janssen, J.J. Bamboo in Building Structures. Ph.D. Thesis, Technische Hogeschool Eindhoven, Eindhoven, The Netherlands, 1981.

23. Molari, L.; Mentrasti, L.; Fabiani, M. Mechanical characterization of five species of Italian bamboo. Structures 2020, $24,59-72$. [CrossRef]

24. Molari, L.; García, J.J. On the radial variation of the transverse mechanical properties of bamboo. J. Build. Eng. 2021, 33, 101557. [CrossRef]

25. Masi, A.; Vona, M. Vulnerability assessment of gravity-load designed RC buildings: Evaluation of seismic capacity through non-linear dynamic analyses. Eng. Struct. 2012, 45, 257-269. [CrossRef]

26. ISO/DIS 22156:2020. Bamboo-Structural Design; International Organization for Standardization: Geneva, Switzerland, 2020.

27. ISO/DIS 22157:2019. Bamboo-Determination of Physical and Mechanical Properties of Bamboo Culms-Test Methods; International Organization for Standardization: Geneva, Switzerland, 2019.

28. ISO 12122-1:2014. Timber Structures_Determination of Characteristic Values_Part 1: Basic Requirements; International Organization for Standardization: Geneva, Switzerland, 2014.

29. Regulamento Colombiano de Construccion Sismo Resistente. Titulo G-Estructuras de Madera y Estructuras de Guadua. Comision Asesora Permanente para el Regimen de Construcciones Sismo Resistente. (Colombian Normative). Available online: https:/ / www.culturarecreacionydeporte.gov.co/sites/default/files/reglamento_construccion_sismo_resistente.pdf (accessed on 24 May 2021).

30. Circolare 21 Gennaio 2019, n. 7 C.S.LL.PP. Istruzioni per l'Applicazione dell'Aggiornamento delle “Norme Tecniche per le Costruzioni" di cui al Decreto Ministeriale 17 Gennaio 2018. Supplemento Ordinario alla Gazzetta Ufficiale, n. 35 del 11 Febbraio 2019—Serie Generale. Available online: http:/ / sttan.it/norme/NTC2018/NTC2018_Circ_21_01_2019_n7-CS_LL_PP.pdf (accessed on 24 May 2021).

31. D.M. 17 Gennaio 2018. Aggiornamento delle «Norme Tecniche per le Costruzioni». Supplemento Ordinario alla Gazzetta Ufficiale, n. 42 del 20 Febbraio 2018—Serie Generale. Available online: https://www.gazzettaufficiale.it/eli/id/2018/02/20/18A00716/sg (accessed on 24 May 2021).

32. Vona, M.; Mastroberti, M. Estimation of the behavior factor of existing RC-MRF buildings. Earthq. Eng. Eng. Vib. 2018, 17, 191-204. [CrossRef]

33. Sharma, B.; Gatóo, A.; Bock, M.; Ramage, M. Engineered bamboo for structural applications. Constr. Build. Mater. 2015, 81, 66-73. [CrossRef]

34. Baumert, C.; Baur, M.; Garrecht, H.; Heinsdorff, M.; Kahn-Ackermann, M.; Knapp, G.; Morsy, M.; Ott, A.; Sieder, M.; von Vegesack, A. The Bamboo Architecture Design with Nature; Hirmer Verlag München: München, Germany, 2010; ISBN 978-3-7774-2791-1.

35. Kaminski, S.; Laurence, A.; Trujillo, D.J.A.; King, C. Structural use of bamboo: Part 2: Durability and preservation. Struct. Eng. 2016, 94, 38. 